Company.-Popular Lectures, Ludwig Boltzmann; Geometry, René Descartes, translated ; Ausdehnungslehre, Hermann Grassmann, translated; A Memoir of the Life and Work of P. E. B. Jourdain; Precritical Essays on Space and Time, Immanuel Kant: Civilisation and Mechanics, Ernst Mach; Knowledge and Error (Erkenntnis und Irrtum), Ernst Mach; Principles of the Theory of Heat, Ernst Mach; The Aims of Scientific Method, and other Philosophical Essays, Dr. T. Percy Nunn; Essay on Non-Euclidean Geometry, Georg Reimann; American and English Pluralist Philosophers, Jean Wahl : Relation of Space and Time to Experience, Norbert Weiner; An Appreciation of Bhagavad Gita ; The " Open Court" Classics of Science and Philosophy: Vegetable Staticks, Stephen Hales, edited, with notes, by Sir Francis Darwin; Arithmetica Infinitorum, John Wallis, translated and edited by J. M. Child ; Carnot: Motive Power of Heat, edited by A. E. Heath; De Morgan's Formal Logic, edited by A. E. Taylor. Oxford University Press. - The Metaphysics of Aristotle, Prof. W. D. Ross, 2 vols. An Essay concerning Human Understanding, John Locke, abridged and edited by A. S. Pringle-Pattison; Spinoza, Descartes, and Maimonides, L. Roth; Speculum Mentis or The Map of Knowledge, R. G. Collingwood; Theories of Memory, Beatrice Edgell. University of London Press,
Ltd.--Personality, Dr. W. Brown. University Tutorial Press, Ltd.-Social Psychology, R. H. Thouless. Williams and Norgate.-Social Aspects of Psychoanalysis, edited by Dr. E. Jones: Man and the Individual, Dr. J. Glover; The Family, J. C. Flugel; Politics, Dr. M. D. Eder Education, Miss Barbara Low; Vocation, Miss E. Sharpe.

\section{Technology.}

Ernest Benn, Ltd. - The Resources of the Empire Series, comprising twelve self-contained volumes dealing with the following industries: Food Supplies: Timber and Timber Products; Textile Fibres and Yarns; Fuel ; Rubber, Tea, Cacao, and Tobacco, with Special Sections on Coffee and Spices; Leather; Chemicals; Ferrous Metals; NonFerrous Metals; Oils, Fats, Waxes, and Resins; Communications. Chapman and Hall, Ltd.--The Technology of Wood Distillation, Dr. A. Rule. Methuen and Co., Ltd.Sugar Refining, Past and Present, J. L. Fairrie. Sir Isaac Pitman and Sons, Ltd.- The Button Industry, W. U. Jones Bread and Bread Baking, J. Stewart; Weaving, W. P Crankshaw; Woollen Yarn Production, T. Lawson. Scott, Greenwood and Son.--Art of Lithography, H. J. Rhodes, new edition; Drying by Means of Air and Steam, E. Hausbrand, new edition; The Manufacture of Paint, J. C. Smith, new edition.

\title{
Reflecting Telescope for Simeis Observatory, Crimea.
}

THE Imperial Russian Government in I9I2 ordered from Messrs. Sir Howard Grubb and Sons, Ltd., a forty-inch reflecting telescope, and the preliminary designs for the instrument were made in collaboration with Dr. Belopolsky, the late Dr.

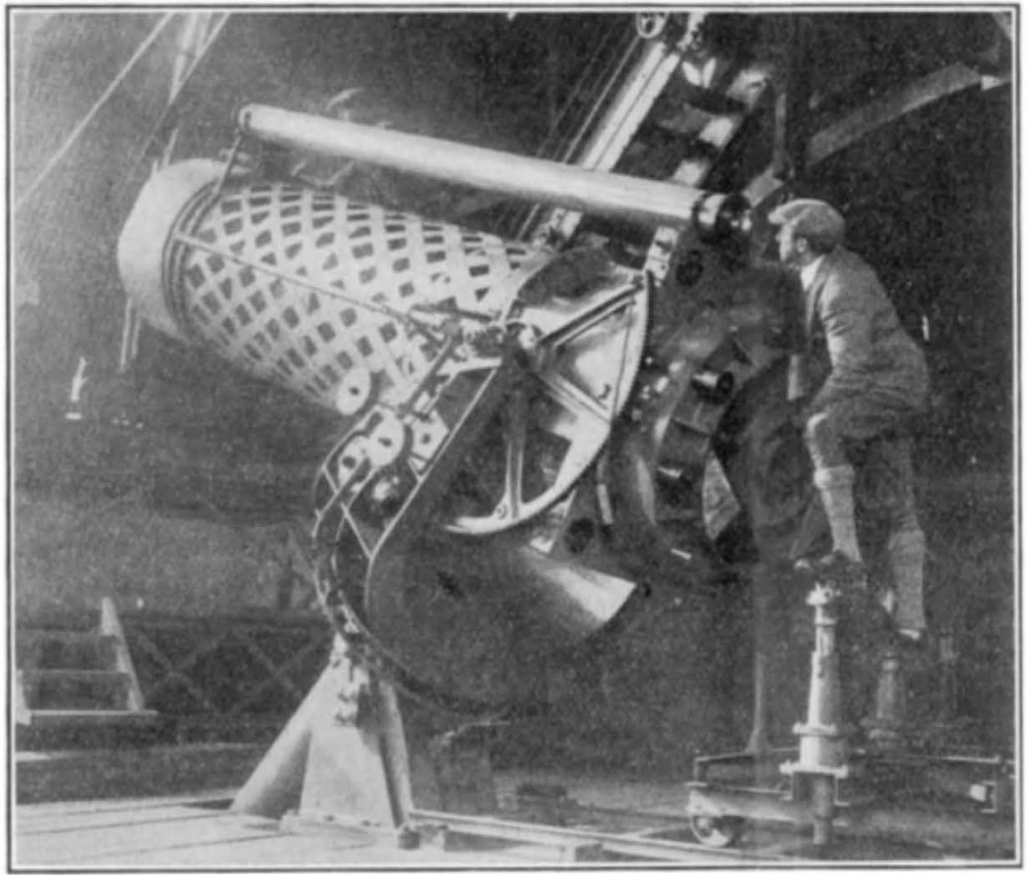

Fig. 1,-Forty-inch reflector for Simeis Observatory, Crimea.

Constructed by Sir Howard Grubb and Sons, Ltd. overhung fork. The main part of the stand, below the level of the floor seen in the illustration, is of massive construction, and is made in five parts for convenience of transit; it contains the driving clock, and mouse feed, automatic and hand controls. The driving circle is six feet in diameter and mounted towards the lower end of the polar axis, connected to the Right Ascension clamp ring by a Clement Driver. The Right Ascension clamp is actuated by a solenoid, which is automatically locked when the clamp comes into action, a second and smaller solenoid being used to unlock it. These solenoids, as well as the motor for quick motion in Right Ascension, are controlled by push buttons mounted at the upper end of the tube, interlocking arrangements being provided so that the motor cannot be started while the telescope is clamped. They can also be operated by a hand controller from any convenient position.

The fork in which the tube is mounted is a massive steel casting, and is bolted to a flange formed on the upper end of the polar axis. Immediately below this flange is strung the Right Ascension Circle, which is $3 \mathrm{ft}$. $6 \mathrm{in}$. in diameter and driven by the driving clock, independently of the polar axis; this circle, as well as the Declination Circle, which is mounted inside the fork, can be read from both the upper end and the great mirror end of the tube. The centre portion

Backlund, and Sir David Gill. In 1922 instructions were received from the Soviet Government to complete the instrument, and it is now undergoing tests at Messrs. Grubbs' works at St. Albans.

The telescope, which is shown in Fig. I, has an aperture of I metre, and focal length of 5 metres, and is somewhat similar in form to the sixty-inch reflector at Mount Wilson, the tube being mounted in an NO. 284 I, VOL. I I 3$]$ of the tube, to which the trunnions are attached, is of cast iron, generally of octagonal cross section formed with a flange at the side on which an eyepiece or spectrograph can be mounted when the telescope is used as a Cassegrain. The lower portion has a circular flange to which the mirror cell is bolted.

The glass mirror, $40 \frac{1}{4}$ inches diameter and 8 inches thick, weighs about $900 \mathrm{lb}$., and is mounted on a 
system of levers so arranged as to cause an equal pressure on 9 out of 12 portions of equal area of the lower face of the mirror, the remaining 3 portions being supported on adjusting screws for squaring the mirror. Nine weighted levers mounted on universal joints compensate for the side pressure of the mirror, these levers being out of action when the tube is vertical, and gradually coming into action as the tube is moved towards the horizontal. These systems of levers are similar to those used in the sixty-inch Mount Wilson telescope.

The main part of the tube is built of flat tapered strips of duralumin laid in right- and left-hand spirals and stiffened inside at intervals with steel angle rings, the upper end of the tube having a flanged ring to which either of the two hoods provided can be attached. The first, or Newtonian hood, is provided with a handwheel, so that it can be rotated to bring the eyepiece into a position convenient for the observer, the diagonal mirror being supported by four thin steel bands five inches wide, placed edgewise. On the side of this hood is mounted a flange to which either a visual or photo breechpiece can be attached by a bayonet joint-while a little to one side is placed a finder having an aperture of two inches. The photo breechpiece is arranged to take plates $80 \mathrm{~mm} . \times 80 \mathrm{~mm}$., and is fitted with cross slides and guiding microscopes.

The second or Cassegrain hood has a box-shaped aluminium casting mounted in the centre and supported on four thin steel bands. The Cassegrain mirror of 12 inches diameter, with its focussing arrangements, is attached by a bayonet joint to the lower face of this casting, and the Newtonian photo breechpiece can be attached to the upper face, so that when the Cassegrain mirror mounting is removed, photographs can be taken in the prime focus. The mirror focussing gear is actuated by a handwheel mounted at the lower end of the tube. The rays reflected from the Cassegrain mirror are received on a small diagonal mirror mounted on four springs about twelve inches in front of the great mirror and reflected at right angles to the axis of the tube through the flange formed on the side of the centre casting, arranged to take the breechpieces or spectrograph.

The telescope is also arranged so that a fixed spectrograph can be used. For this purpose a plane mirror is provided which can be mounted on a hollow shaft passing through one of the trunnions forming the declination axis, this mirror being arranged to move at half the speed of the tube when the latter is moved in declination. This mirror directs the rays from the Cassegrain mirror down through the hollow polar axis. Fixed on one side of the tube is a guiding telescope of 7 inches aperture and about I 3 feet focal length, fitted with eyepiece on cross slides.

The quick, quick-slow, and slow-slow motions in Right Ascension, as well as the quick motion in Declination, are all electrically operated and controlled by push buttons from any convenient position.

The telescope is mounted in a revolving dome of 32 feet internal diameter, carried on steel pillars I6 feet high, a floor being attached to the pillars I 2 feet above the level of the ground. The dome has a double shutter giving an opening II feet wide at the bottom, $5 \mathrm{ft} .6$ in. wide at the top, and extending 4 feet beyond the zenith. The observing platform is carried on rails mounted in the revolving portion of the dome, and has a transverse motion of about 4 feet parallel to the opening. This platform has a stairway attached to it, with rails on each side of the steps, at an angle of $45^{\circ}$, up and down which runs the observing carriage, controlled electrically, and fitted with cut-outs to limit the travel. The revolution of the dome can be controlled from this carriage, or any other convenient position.

A truck fitted with three screw-jacks is provided for removing the mirror cell and mirror from the tube, and for raising the mirror out of the cell, for the purpose of resilvering.

\section{New Agriculture Building at the University of Leeds.}

$\mathrm{O}^{\mathrm{N}}$ Friday, April 4, the Rt. Hon. Noel Buxton, Minister of Agriculture and Fisheries, laid the foundation stone of the new building for the Department of Agriculture at the University of Leeds. The proceedings were presided over by the Chancellor of the University (His Grace the Duke of Devonshire), and after the laying of the stone the Minister gave an address at a public meeting in the Great Hall of the University. There was a large company of landowners, farmers, and other friends of the University present, and much interest was manifested in the proceedings.

The building, which has been designed by $\mathrm{Mr}$. Paul Waterhouse, will occupy a plot r9o feet long by I 25 feet deep. The basement will be used for stores, and will also contain a students' common room, and a large machinery room and workshop, etc. On the ground floor there are two lecture rooms, a museum, library, and administrative offices. The Biological Department on the first floor will include a general laboratory, lecture room, research rooms, an advanced laboratory, one or two private rooms, preparation, sterilising, and store rooms, etc. The Chemical Section is provided for on the second floor, and includes a large students' laboratory, laboratories for chemical nutrition research, balance rooms, large and small lecture rooms, and rooms for microscopy and other special purposes. The roof surface will be adapted for out-of-door and greenhouse work. The new building will cost $60,000 l$, towards which the
Government have promised a grant of I $5,000 l$., and the Yorkshire Council for Agricultural Education Io,oool., while there have been also some handsome donations.

At the meeting in the Great Hall of the University after the ceremony, the Duke of Devonshire, in extending a cordial welcome to $\mathrm{Mr}$. Buxton, indicated the opportunity which the new building would afford to enable research work to be carried on under more comfortable, happier, and favourable conditions. He hoped this would only be an augury of further development.

Major Dent, chairman of the Yorkshire Council for Agricultural Education, spoke of the progress of the work of the Department of Agriculture of the University since its establishment in I89r, and of the principles which had guided the Council. There was one body responsible for agricultural education for the whole geographical County of Yorkshire, consisting of representatives of the three County Councils, the University, the Ministry of Agriculture, and a few additional members. He referred to the amicable relations that had existed amongst the various authorities, and how co-operation and interest had been secured with the Farmers' Union. Much had been accomplished from a small beginning in the domain of agricultural economics, and great extension had taken place in the advisory work of the Department.

Mr. Noel Buxton, in referring to the honour it gave

NO. 284 I, VOL. I I 3 ] 